\title{
CARAVAN COLLECTIVES: \\ URBAN ECOLOGICAL EXILE \\ IN MILITANT MARGINAL SPACES
}

\author{
A B S T R A C T
}

The vehemence with which poverty persists in new EU states presents significant challenges for those interested in housing advocacy for the urban disadvantaged. Post-communist states like Poland have inherited anunenviable legacy of dilapidated Communistblock housing presenting contemporary conditions that include concentrations of violent crime, an assault upon aesthetic sensibilities, and severe impediments for sustainable living. Other housing alternatives are the massive residential construction projects underway by foreign developers, resulting in false scarcity and spiraling costs. In response to these deleterious conditions, anarchist activists with a penchant for ecological living have advanced another alternative to the housing crisis through mobile architectural anarchy ${ }^{1}$. By recycling mobile architecture in the form of abandoned retro-fitted train wagons and traveling in small materially-unencumbered communities, these groups or caravans tend to informally settle or squat in peripheral, discarded environmental areas in cities to advance selfsufficient sustainable lifestyles known as urban homesteading ${ }^{2}$. These migrant housing pioneers, known as the new hobos ${ }^{3}$, have embraced their subaltern status, accepted their identity as stateless citizens in permanent exile and advanced nonhierarchical sustainable lifestyles. The analysis will provide a case study of participatory observation at Poland's eco anarchist caravan collective, describe barriers to collective action, and frame the phenomenon in light of the utility of marginal territorial squatting to inspire European housing policy to expand this egalitarian housing solution for cities in the future. 


\section{INTRODUCTION}

Cities are currently experiencing an unprecedented struggle in the competition over public space. Powerful businesses, governments, and individuals all attempt to influence zoning policies that determine the allocation of, and access to, valued urban areas. On the one hand, market-driven analyses often identify the value of urban districts arbitrarily, based on a variety of capitalist-oriented criteria such as proximity to services, institutions and other accoutrements required for conventional culture. On the other hand, non-market-oriented, unconventional city inhabitants - often in state or self-imposed exile - tend to subscribe to an entirely different ideological and material value system whose urban ethos has little in common with powerful conventional elites. As such, these unique inhabitants rarely compete for access to the same urban resources. Although conventional architectural and urban development decision-makers tend to perpetuate artificial demand and false scarcity for properties offering proximity to conventional city services they deem as necessary for a high quality of life, many inhabitants not subscribing to these mono-cultural worldviews benefit exponentially from existing arrangements. While conventional elites rush to occupy certain centralized territories of the city, they simultaneously abandon others. As a result of shifting centers of urban cultural production, marginal ecological spaces often become available for those interested in appropriating them for alternative sustainable inhabitation. The creative use of these marginal spaces by unconventional disenfranchised residents provides the materially-unencumbered city dweller with opportunities for potentially liberating and emancipatory activities. Those willing to deploy innovative tactics can temporarily appropriate these neglected peripheral territories through animated mobile living.

Such unique systemic arrangements have fostered the development of networks of mobile, postindustrial, ecological caravan collectives known as Wagonburg. While many transient Slavic, Arabic and other ethnic communities across Europe, the Middle, and Far East have a fascinating history of materiallyunencumbered collective travel in caravans, contemporary inhabitants in post-communist urban environments have recently popularized these ancient practices using the old German vernacular. These urban inhabitants, in and beyond control of the communist regime-designed, capitalist regime-modified, colonized city are helping to [re] establish traditional enclaves of geographically unrestricted, demographically-diverse, nonhierarchical, noncompetitive concentrations of uncommodified cultural production. These informal postindustrial land occupation schemes involve the temporary inhabitation of undeveloped spaces in and beyond the urban center at comfortable 
distances from the aristocratic gaze. Through lively, animated, residential and recreational sustainable living and preservation activities taking place within caravans of abandoned, retro-fitted, train wagons on wheels; the innovative transgression and denial of commercial space in the central city formalizes and legitimates not only caravan residents but also other concerned stakeholders subscribing to these same post-material, postindustrial, sustainable lifestyles. Thanks to the economic impact associated with successful experimental inhabitation models being attempted by both residents and supporters in these unique Wagonburg communities, city planners are just starting to understand and accommodate these militant entrepreneurs. Their experimental models of sustainable mobile living include creative occupation and stewardship of green marginalized territories within and beyond city boundaries through nonbureaucratic collective decision-making. Before proceeding further it may be useful to theorize the enormous potential of this innovative urban experiment taking place in discarded post-communist spaces in greater detail.

\section{BACKGROUND}

According to the data presented by the World Values Survey material and other values vacillate significantly by culture, age, gender, race and class ${ }^{4}$. Thus it is no surprise that the value assigned to urban resources differ significantly by inhabitant's culture, age, gender, race and class. Predictably, those excluded from conventional city center development would wish to appropriate marginal spaces discarded by elites. The new centers that arise due to capitalist-driven urban planning tend to lead to a multiplicity of power axis centers, often pushing unconventional bohemian inhabitants toward underdeveloped, primitive green spaces. Postindustrial conditions have had enormous impact on the ways in which mobile alternative inhabitants in exile occupy these experimental spaces. Conventional wisdom of architects and urban planners suggests that city dwellers consistently wish to maximize their status through the ostentatious display of wealth, particularly through their residential dwellings. According to Kennedy,

The case of the value of residential homes is particularly pertinent, since much of the wealth of cities is reflected in such properties. Homes provide a good deal of utility - warmth, shelter, security, and comfort. The value of the home also reflects embodied labor, not just to construct it but also to provide all the raw materials and infrastructure to service it. Scarcity of location - such as proximity to an alluring downtown core, or a posh, sought-after neighborhood - is another important attribute of housing value. Labor, utility and scarcity are all important dimensions of value, 
then, but there is another ingredient that also needs to be considered one that is crucial to understanding the wealth of cities. That ingredient is spatial context. A problem encountered by those concerned with social and natural capital is that many so-called goods are actually undesirable. ${ }^{5}$

Prime city spaces are subdivided, allocated and restricted by conventional elites for conventional elites according to criteria that fluctuate by arbitrary values that are not necessarily ubiquitous among all city inhabitants. Access to city spaces fostering conventional culture may, in fact, be very undesirable for those being excluded from business and leisure activities that reproduce the existing class structure. The argument claiming an alleged universal demand for ostentation housing is also dubious under postindustrial conditions, as elaborate structures do little to address sustainability and instead signal a lifestyle indicative of conspicuous consumption and an orientation toward a wasteful, indulgent, material ethos.

\section{ESCAPING CAPITALIST COLONIZATION OF THE CITY}

Because most urban environments reek of social exclusion and poverty, there are many superfluous urban populations who not only accept their marginality but embrace the post-material sensual austerity that often accompanies bohemian exile in the underdeveloped discarded green spaces of the city. But this is not to suggest that the process of experimental escape is without conflicts. Enormous tensions do exist, as historic centers become marginalized and marginalized spaces subsequently become new centers in demand by pluralistic inhabitants. These represent a significant upheaval, especially when these centrifugal changes are influenced by foreign investors and other exogenous decision-makers. This shifting of authoritarian spaces, as well as the tensions they bring about, are especially pervasive in postcommunist urban environments affected by tectonic changes brought on by simultaneous economic, political and cultural transformation all at once. According to Body-Gendrot,

[T] he market does not favor social cohesion but generates tensions: it reinforces economic polarization and inequalities in cities, the recomposition of space unveils power conflicts among major actors and hundreds of thousands of marginalized people and their children may use their "voice" as a threat to express their claims. The range of local decision varies from the destruction of public housing, the termination of rent control, evictions and the withdrawal of municipal services, to taxbreak incentives, mortgage assistance and zoning restrictions pushing 
for the spatial replacement of poor populations by reliable tax payers, either companies or private individuals. What amount of depacification is intolerable? It would be a short-sighted view to ignore the power of the powerless. The margins of society can hit the center at its core. Under the effects of the imposition of a new centrality and once there is nothing to negotiate, the marginalized, whether they live in the inner cities of the first world or elsewhere, are not powerless: they can always negate what is a precious good for the others: social peace. ${ }^{6}$

As the power elite of the world system business sector core opportunistically expands into these newly 'liberated' post-communist peripheral territories ${ }^{7}$ and as European 'harmonizing policies' involuntarily brought on by the technocrats of the EU increasingly lead to profoundly antagonistic normative social controls of city spaces, inhabitants are acutely affected by pro-business policies that colonize urban territories and remove indigenous populations from the public spaces that were once their own. These processes have been well documented in Prague, Budapest and many other post-communist world capitals. Poland is no exception. But these changes do not lead to powerlessness of the displaced masses. Quite the contrary, there is evidence that innovative adaptation by superfluous displaced inhabitants is well underway. What forms of creative resistance are observable?

In the face of more and more exogenous capitalist control of post-communist urban territories, unprecedented forms of resistance are taking place in the form of informal urban antidevelopment through ecological preservation of the abandoned and neglected spaces left behind by aristocratic public and private sector elites. In this way, diverse voices are informally influencing the tapestry of marginal spaces in and beyond the city center. According to Slessor,

There are $[\ldots]$ signs that the reductivist legacy of the twentieth century planning orthodoxies is at last on the wane. It is now possible to conceive of a more humanly rich texture of development capable of promoting strong and varied expressions of city life. Set against the homogenizing tendencies of planning and big business is the recognition of the need to re-animate the city to provide a backdrop for its essential rhythms and dramas. Such an architecture can emerge if contemporary technology is sensibly appropriate to serve public needs. The key to success $[\ldots]$ is diversity. Successful cities are those that encourage heterogeneity and the interaction of functions, typologies and activities, and in doing so enhance the lives of ordinary citizens. ${ }^{8}$ 
The relative success of the diversity-oriented, anarchist-primitivist collective temporarily inhabiting green, discarded, marginalized spaces in Polish cities such as Wroclaw is starting to attract the attention of a broad constituency of interested audiences. The resilience and continued triumph of the experimental mobile caravan represents an enormous threat to capitalist elite, the status of which is contingent upon systemic arrangements that require geographic stability, pacification, complacency and dependency of the working classes driving the capitalist machine. The revolutionary potential of taking back urban spaces have long been theorized in Situationist manifestos such as the plan advocated by Kotanyi and Vaneigem, which states that it is in the interest of urban inhabitants to develop

an inclination to transgress national boundaries and everyday alienation, [to] reconstruct the environment and appropriate resignation, [to resist becoming] cities slaves - enslavement to capitalism, routine imprisonment; [and to exhibit a] rejection of fixed norms and permanent solutions as the basis for town planning - [to instead embrace] the basis for experimental life. ${ }^{9}$

As Sadler reiterates, the reanimation of life in the city was crucial to the Situationist revolution. The creative reanimation of discarded green spaces, often mired in ruin and rubble, is currently taking place through experimental models of sustainability exhibited by Poland's Wagonburg Collective of Wroclaw and many others like it.

The concept of the collective caravan is indeed a revolutionary model for living. With little to no commercial exchange, low to no rental expenditures, the potential for swift and timely escape of encroaching elites and the opportunity to blend enormous volumes of untapped human capital to provide alternative sources of collective services and other communal support; are all factors that make these mobile community experiments an influential force in the contemporary tapestry of urban avant-garde life. [Re]creating sustainable and sometimes refreshingly primitive systems to fulfill requirements for necessary collective services such as sewerage, refuse composting, clean water and alternative energy; these experimental utopian communities of mobile, sustainable caravans adhere to an entirely innovative lifestyle not contingent upon enslavement to exploitative secondary tier labor opportunities at the subhuman wages offered by western corporations that barely enable post-communist citizens to survive. The emancipatory potential for creative use of leisure time, the development of alternative recreational institutions, the rise of nonhierarchical problem-solving, innovative self-governance and 
a whole host of other self-sustaining activities represents nothing short of a utopian plan for revolutionary urban living. According to Woods, the need has never been greater.

The New City is [...] a world of self-realization promised by the history of liberal democracy, and no less, a world of transcendent materialism. In the present technological society, innovation has already begun to race ahead of tradition. New knowledge, new conditions of living are developing faster than they can be thoroughly assessed and tested, or their effects controlled. Inevitably, these conditions will force changes in thinking and in society. From these changes may emerge the promised world.

\section{CHALLENGES TO UTOPIAN LIVING}

\section{Food}

While the potential for a diverse, pluralistic, egalitarian world to emerge from these arrangements is enormous, the journey is fraught with challenges. Material consumption is perhaps the greatest challenge and food figures prominently. Principles associated with urban homesteading suggest that land use, however small, can be maximally utilized through small scale agricultural production for self-sufficient lifestyles. Poland's long and difficult winters limit the availability of fresh produce and many anarcho-primitivists and anarchofeminists associated with experimental caravan collectives maintain traditional canning, pickling and drying practices necessary for seasonal human survival for centuries. Interestingly, the circulation of this indigenous knowledge is largely reliant upon intergenerational matriarchal discourse, so that little has been lost in terms of Slavic women's oral traditions. But a steady supply of self-sufficient food remains precarious, as land occupation is prone to frequent changes, and is usually at the whim of idiosyncratic public and private sector elites who vacillate wildly in their support of caravan squatting. This wavering support is also sensitive to public sentiment and much effort is invested in public information campaigns to offset the routine vilification disseminated by urban politicians whose status is threatening by those advocating autonomous lifestyles through demonstrated examples. Yet the primacy of independent food production and the rise of these caravan collectives as an egalitarian space to accommodate anarcho-feminist sensibilities, nevertheless, remain highly innovative in terms of cultural transmission of Slavic domestic practices. The unique cultural and ideological intersectionality surrounding mobile anarchist food production fosters the simultaneous support and articulation of Slavic feminism as well as the preservation of feminine agrarian cultural traditions. 
The new forms of interpretation of indigenous knowledge surrounding food production and consumption give rise to new forms of labor division not rooted in archaic gender roles. These are just some of the many revolutionary egalitarian potential provided by these new anarchist caravan living arrangements in post-communist urban territories. As Lemecha reminds us, the anarcho-feminization of kitchens and other city spaces provides opportunities to resist dependencies upon GMOs and other forms of patriarchal agrarian exploitation associated with corporate food production. ${ }^{11}$

It is significant that "space" rather than architecture is [the topic], inviting us to consider that which includes but is not limited to the office tower, the city, the house. These spaces weave through and around structures and that which dictates results from their particular configuration: freedom, confinement, sanctuary, threat, history and ideology to name a few examples. Unlike the patriarchal constructions that attempt to control and contain at the first sign of disorder, these feminist reconstructions glory in leaving the gates of orthodoxy open to hasten their escape. ${ }^{12}$

Revolutionary agrarian potential is rooted, therefore, not in the colonized, sanitized city center, but rather in the urban, Slavic, squatted caravan kitchen and other autonomous collective spaces. It is here where a [re]evaluation of feminist contributions to non-corporate food acquisition and other forms of indigenous collective cultural survival provided the fortitude needed to endure long harsh winters. In this way the return to women-based indigenous knowledge surrounding food preservation generates egalitarian gender role sentiments among many utopian caravan inhabitants.

\section{Territory}

Squatting of these marginal territories represents another challenge for these experimental urban lifestyles. Ownership is rarely respected and stewardship is an uneven process. The more human investment in these marginalized spaces as evident in lively interaction with the land, the more threatening the inhabitation is for conventional elites. In the case of Wagonburg Wroclaw, not only was an environmental land parcel on an undevelopable floodplain between two river tributaries successfully squatted, but neighboring buildings on private lands adjacent to the caravan collective were fully utilized as alternative spaces for live music, art galleries and other recreational activities. These recreational events were enormously popular and wildly lucrative operations for the collective. Many supporters in the community not residing in the Wagonburg contributed to the sophistication of these parties, by contributing massive generators, live band music, recording systems, DJs and other club-like accoutrements. But 
the unexpected success and related community legitimacy brought with it an increase in threats from the state, due to the absence of taxation benefits for the city. This uneasy tango actually enabled the collective to occupy the lands and building even longer than expected, due to community support and the lack of competing venues. This led to a tenuous relationship between the Wroclaw city government and the Wagonburg collective that can only be described as precarious accommodation. The precariousness of squatting, according to Rendell, is an emancipatory but highly vulnerable act.

Squatting can say things about the construction of identity, the display of a distinct social status in relation to conventional lifestyles. In search of their own identity, they refused standardized rules, the principles of structure, $[\ldots]$ and functionalism. Services are installed in a way that challenges institutional codes. [L]ife lived with unstable physical materials becomes fraught with physical dangers. But this life was [...] a challenge to the way [people typically] occupy space and to the relationships we take for granted. It was a rejection of comfort and laziness. There was no room for complacency. You felt your own body in every moment of occupation. ${ }^{13}$

From the perspective of urban planners, architects, zoning and other regulatory agents in the city, building squatting as well as ecological land squatting both represent enormous safety risks due to the lack of liability that is assured through capitalist principles of ownership. The anarchist boundary is limited to the ideological beliefs of the caravan collective, but these experimental territories remain realistically embedded within a litigation-prone western society filled with regulatory constraints. As such it should come as no surprise that over the course of my half-year residency at the Wroclaw Wagonburg Caravan Collective, city officials, private developers and other stakeholders routinely engaged in contractual exchanges with the collective, culminating in risk-reducing limited liability agreements benefiting all the parties involved. I observed similar arrangements at the Wagenburg of Basel, Switzerland, that emerged from the closing of the nearby Freiburg Squat in Germany. As a weeklong visitor in Basel, I was witness to similar legal maneuverings which took place at the highest levels of City Hall. These agreements were undertaken to assure that short-term interests of all parties were being addressed and that sanitary and other expectations were made explicit. In the absence of any long-term legislative agreements for squatters internationally, these frequent but temporary, quasi-legal agreements are surprisingly effective in providing squatters around the world with relatively unfettered temporary access to discarded lands, usually under the guise of ecological preservation and the 
exchange of caretaking stewardship services. According to Sanders, the greening of the urban environment has always paradoxically been the focus of ecological activism.

Despite our long-standing romance with wild places and the association of wilderness with environmental activism, the modern environmental movement $[\ldots]$ was very much an urban focused phenomenon. [M] any politically engaged and environmentally active Americans [...] committed themselves to remaking urban spaces and in the process they laid the foundation for contemporary, and movements. The urban home stood at the center of this new political ethos and domestic urban space $[\ldots]$ was the place where activists connected political concerns as seemingly discrete as gender, the environment, and poverty. Urban consumption served as a fulcrum for these concerns and the urban house an artifact, as well as a set of daily practices, played an important but ambivalent role in social change. As private lives and public politics merged, many $[\ldots]$ began to stretch and re-imagine the idea $[\ldots]$ of a home [to articulate] self-reliance and cultivation of urban nature as a means for survival. ${ }^{14}$

Once a caravan collective stakes a formal claim to marginal, discarded, ecological lands outside the imminent control of developers, little can typically be done to evict temporary preservationist/activist inhabitants until solid development plans are commenced. Vulnerable politicians are operating under the watchful eye of weary, exasperated city-dwelling voters who, more often than not, have been similarly excluded from prime areas of the privatized, colonized city. In this way, conventional urban powers are usurped and accommodation seems a persistent, albeit temporary tactic, enjoyed by these experimental communities for at least a limited amount of time. While quasilegal agreements protecting temporary occupational rights remain fleeting, these mobile caravan collectives are designed in such a way so as to facilitate a hasty escape from squatted territories when necessary.

\section{Size and the Quality of Inhabitants}

Destabilization of the community is not only brought about by exogenous interests. One endogenous downfall that prohibits the maintenance of these temporary legal agreements seems to reside in the free rider problem, which is manifested where community support is high and when opportunists with incompatible work ethics begin to weaken governance and other crucial elements of caravan collective survival. The work involved with establishing the caravan community, locating the resources needed for supporting it 
and finding the proper place to bring the project to fruition required deep commitment that few possess. Once the experiment is successfully underway, supporters flock to the collective without any desire to necessarily sustain the effort needed to keep the collective afloat. Even among founders, Rendall reminds us that political negotiation involved in squatting and other requisite forms of diplomatic interaction associated with utopian experimental lifestyles is profoundly difficult.

Squatting is an activity which resists property ownership and chooses to occupy without buying. It involves the use of premises without permission, without wishing or being able to pay rent. Squatters may use places in ways that may differ from the original design intention. The occupation of places through squatting is more transitory than other forms of residence. Squatters may occupy marginal spaces through social circumstance or political aspiration, but it is important not to over romanticize. Squatters are not always lovely people. Some of the squatters I have known did not live an easy co-existence with each other, let alone the wider community. Problems of exclusion, poverty and the physical hardship of living without decent heating, lighting and sanitation cannot be overlooked. ${ }^{15}$

Few have the stamina to maintain these politically resistant lifestyles for long and the arduous tasks required for daily survival lead to an enormous turnover among residents, which does little to strengthen community within the collective. Furthermore, these collectives tend to attract many supporters long after the difficult infrastructural work has been done. When inhabitants secure lands, dig septic tanks, secure bonfire pits, create community gardens, build wind mills and other autonomous energy sources and carve admirable leisure spaces amenable to the preservation of nature and even occasional massive weekend parties, the value of these caravan communities becomes exponentially inflated. There are even indicators that growth should be limited and that the key to success lies in small-scale caravan collectives operating at a population proportion which can be harmoniously integrated within existing green territories.

\section{Wagon Dwelling Units}

Despite the enormous complications of caravan squatting, perhaps the most innovative but challenging element of the entire experimental collective project is the mobile dwelling unit itself - the retrofitted train wagon. This wagon presents inhabitants with a cheap, efficient, profoundly functional and highly creative mobile space. If necessary, the dwelling is also amenable for a hasty 
escape from illegally squatted lands. As anyone who has lived in Soviet-type communist countries during communist times can attest, these wagons were always used as temporary dwellings, parked in ecological lands at the end of the train line. Routinely used as low-cost summer housing for rail yard workers to enjoy their leisure time during summer holidays, it was only a matter of time before this communist era practice, like so many before it, became passé and obsolete. As such it was no surprise that the humble industrial communist relic, the People's train wagon dwelling, would eventually become popular among anarcho-primativists reeling from scarcity associated with extreme capitalist class disparities and postindustrial unemployment.

Many of the anarcho-primitivists I lived with in Wagonburg Wroclaw spent their childhood vacations in these mobile dwellings with a father or uncle working in the transportation industry. The persistent use of the German term, according to local Polish folklore, reflects the fact that anarchist activists in East Berlin were apparently the first to politically appropriate these dwellings in their efforts to resist developers and transcend the spiraling costs of housing in the communist sector of Berlin.

Whatever their legacy, these Wagonburg caravan collectives now represent a solid residential tactic in political resistance repertoires among housing activists in post-communist nation-states. These caravan collectives once composed of dilapidated train wagons abandoned in the rust belts of Eastern Europe, are now evolving into technologically-renovated, energy-efficient housing units for the homeless that are formally connected through an active and politicallyviable network of European squatters not limited to post-communist societies. Communication taking place in relationships throughout the network assists members in the location, acquisition, resale and application of retrofitting technologies. The circulation of relevant information has together strengthened the comfort of these dwellings, as well as the political potential of these mobile, transnational, borderless, caravan communities. Given the new avant-garde demand for these unique inhabitable objects, recycling and transportation of these discarded industrial relics now necessitates scavenging truck and ship yards throughout the EU. The conversion of these units from railroad track to road-ready mobility entails an enormous amount of cooperation, equipment and engineering competence. Efficient, sustainable, emerging technologies fostering autonomy and independence from municipality-brokered services only enhance the status and investment of these wagons as permanent symbols of post-material living in the emerging age of urban sensual austerity. Thus the hybridization of traditional, indigenous, recycled, industrial transportation 
materials, coupled with grid-free technological energy capabilities, enables caravan inhabitants to collaborate on the emergence of a scientific housing innovation designed to accommodate the needs of progressive ecologists and other green inhabitants eager to usher in a new minimalist era of comfort and stability. According to Slessor

A critical aspect of the interaction between architecture and technology is the way in which they have continually redefined each other. What began as the introduction of rationalized industrialized processes into building construction has evolved into an increasingly diffuse and complex style. This sensibility now embraces wider concerns, including place-making, social responsiveness, energy use, urbanism and ecological awareness. Instead of being unthinkingly glorified, technology is more selectively exploited to achieve particular ends. ${ }^{16}$

These innovations could, given the appropriate response from public sector authorities, eventually solve and eliminate housing problems in all the world's greatest cities. For now, these caravan communities represent a cutting-edge approach in creative sustainable living for those wishing to respectfully occupy marginal urban green spaces. This new mobile housing movement, along with its powerful network, enables inhabitants to make profound contributions to the contemporary city, by enhancing the diversity of its people and the ideological and material perspectives found there. These together make up the unique cultural products driving modern urban territories. Cochrane calls this urban pastiche an assemblage.

[W] deploy the notion of cities as assemblages, a rubric under which to frame the travels and transfers, political struggles, relational connections, and territorial fixities/mobilities brought together to constitute urbanism. Assemblages [...] reconstitute wider flows, thus continually refiguring geographies of territoriality and relationality [that reconcile] tensions. ${ }^{17}$

\section{BARRIERS TO UTOPIAN INHABITATION}

Not everyone is fascinated with, or supportive of, utopian experimental train wagon living. The notion of mobility in the city is considered by urban planners to be a profound liability for community building, particularly given the freedom associated with external or self-imposed exile. Although urban nomadism is generally frowned upon by conventional elites for a variety of reasons, there is evidence that more and more young people are embracing the freedoms associated with creative homelessness brought on by contemporary socioeconomic conditions. According to Romanienko 
Not only does modernity create the conditions that coerce reluctant but authentic individuals with a conscience to live under permanent conditions of forced exile, but it also results in a peculiar role for the body as it attempts to adjust to the unique circumstances of its own societally imposed marginality. Without territory, the nomadic exile has essentially nothing left to lose and forges social bonds among those experiencing these increasingly common forms of drifting disembodiment found in immediate proximity. Without conventional ties weighing the body to space, place, or other elements of material culture, the fortitude and resilience necessary to survive these demoralizing conditions of modernity leads not only to explorations of intense relationships with each other, but also to technology [and] science.

If creative ways are emerging to collectively reconcile the somewhat demoralizing status of forced exile in the city, Harries reminds us that these new found freedoms represent enormous opportunities, but run the risk of weakening tied to conventional community culture.

The lure of freedom that challenges the binding power of place is as old as humanity. Attempts to diminish [...] distance did not have to wait for modern technology. Certainly it must bring with it increased rootlessness. Along with this goes greater anonymity, the substitutability of individuals. Inseparable from such rootlessness is not only a loss of place but a loss of community. Consider today's mobile homes. [T] hese units are difficult to move and rarely moved, yet they are mobile. Like a tent, the mobile home stands in no essential relationship to the environment to which it happens to be located: it is a home that does not belong to a particular place or region. If there is no essential relationship between the mobile home and its social and physical environment, there is similarly no essential relationship between those who live in such a mobile home and the mobile home itself. The impersonality inseparable from the reduction of the home to basic shelter is uncomfortable because it [...] forces its inhabitants to appropriate it. [Yet] we must not lose sight of the gain in freedom brought about. No longer is place destiny. ${ }^{19}$

While there is no evidence to suggest that home ownership or a lack of geographic mobility is necessarily correlated with civic engagement, Pateman calls the conventional forms of superficial engagement pseudoparticipation. Anarcho-primitivists that I resided with would, in fact, suggest that the severing of ties to colonizing elites in the central city is the primary impetus behind these experimental lifestyles. There is no evidence to indicate that the 
superficial interactions among aristocratic elite in the center city enjoying exclusive leisurely services such as the opera, the theatre, or the gallery in the evening have any greater community commitment than the intense ties developed among members of these experimental caravan collectives occupying marginalized lands. Furthermore, the fleeting interaction with natural surroundings, as opposed to permanent destruction of natural habitats to make way for ostentatious dwellings in massive urban development projects, may very well become the desired levels of civic-nature interaction for the future. Setting up a temporary caravan community that does not seek to harness or otherwise control natural surroundings signals a desire to lighten the load of what is now referred to as the ecological footprint. Thus having a dwelling with no permanent relationship with its surroundings may eventually become the ideal post-material approach to sustainable urban residency through light inhabitation. Guallart and Cappelli state

The aim of advanced architecture is not to produce a dwelling that is simply a product of economics. On the contrary, advanced architecture aspires to create the conditions of individual inhabitation, one that meets day-to-day needs, on different scales and at different times. The project of human inhabitation is resolved in a local environment, on the scale of the district, the building, or the individual limits of the dwelling. A self-sufficient dwelling is one that is connected to this local system and knows how to respond to the social, cultural, technical and economic conditions of its surroundings. We must insist that these dwellings adapt their specific qualities to their market price. [W]e need to call for the design and construction of buildings that generate $100 \%$ of the energy they consume, recycle all the water they use and locally generated waste. [This] new paradigm is one of saving and the intelligent use of available resources at an interconnected local level. [To that end, we] should be required to design inhabitable organisms that are capable of developing functions and integrating processes of the natural world $[\ldots]$ and a more intelligent form of inhabitation. ${ }^{20}$

While the recycled post-communist train wagon dwelling represents a superb prototype for experimental ecological caravan collectives, technological and architectural adaptations could be made to reduce its size, enhance its design, and make other necessary improvements that might better accommodate contemporary residency needs under mobility conditions. This will require nothing short of non-exploitation, non-patriarchal, non-dominating, noncommercial commitment of architects, planners, developers, ecologists, and other urban leaders. The key to adapting to these new nonhierarchical ecological 
arrangements rests not only in the development of a materially-unencumbered world view, but also in prioritizing the needs of the collective over the needs of the individual. Thus the success of these experimental homesteading collectives lays not exclusively in the characteristics of the train wagon dwelling unit per se, but in the amalgamation of these train wagons mobilizing in a connected sequence of retro-fitted caravan collectivity. Here emerges what Friedmann calls transformative participation. The transformative civic participation that goes into recreating, rebuilding, reconnecting and relocating these recycled mobile micro-communities within the modern city truly is admirable. According to Moya

In collective, the self-sufficient house voluntarily subordinates itself to the whole, to the higher social entity of which it forms a part, to the collective block of which it is a constituent body. While the primary aim of the dwelling is to be self-sufficient, $[\ldots]$ the ultimate defining objective of the collective is to be self-sufficient, $[\ldots]$ the ultimate defining objective of collective $[\ldots]$ is to integrate and address the block as a whole and to model the public space it generates, while its impact, in terms of the scale of the intervention, has the greatest possible repercussion on the city.

\section{THE FUTURE OF THE CITY}

The ability to rapidly depart from squatted territories is not only precipitated by hostile developers or disgruntled owners, but also by inclement weather. In my half decade of observation and half year of residency at the Wagonburg EcoSquat of Wroclaw, there were several rapid evacuations due to rising tides along the Odra and Olawa River fronts where the caravan was squatting adjacent to an undevelopable flood plain. The absence of state and non-state stakeholder

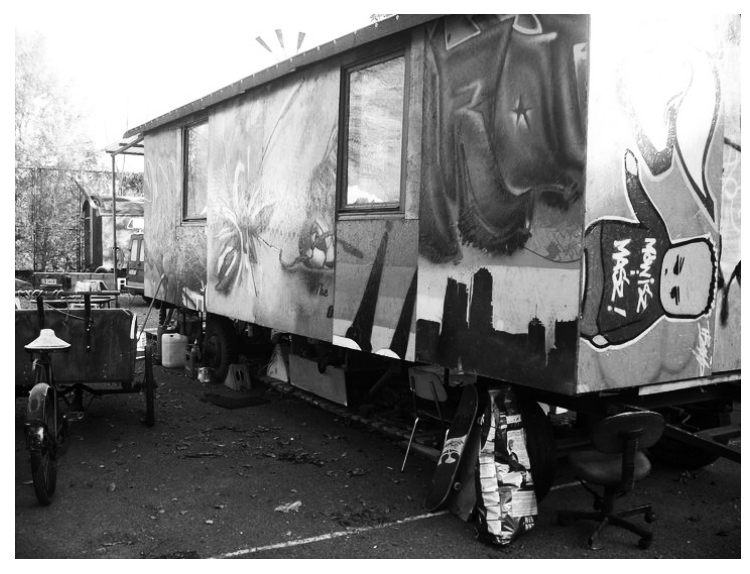

Figure 1 Caravan at the Wagonburg EcoSquat Wroclaw

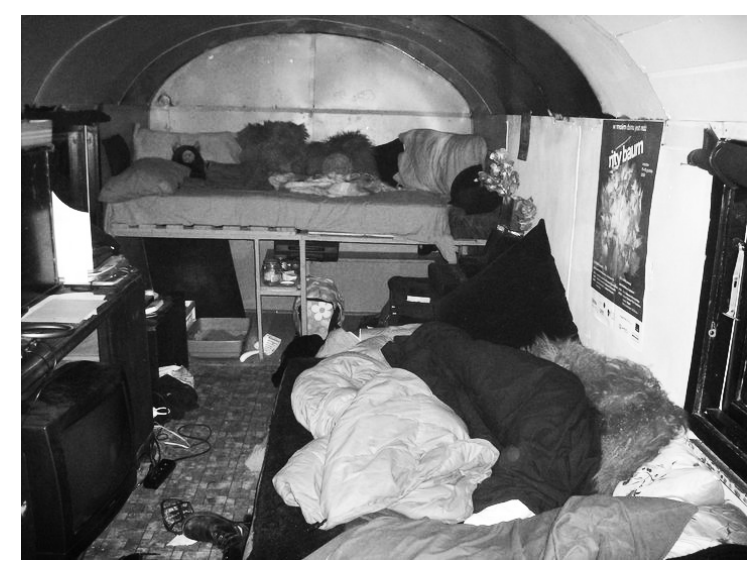

Figure 2 Interior of Caravan at the Wagonburg EcoSquat of Wroclaw 
commitment to adaptation policies that would slow or reverse climate change associated with global warming may eventually compel architects and developers to enhance the design of these mobile experimental communities, perhaps through hydraulic technologies that provide vertical mobility and other forms of light inhabitation enabling climate change refugees to adapt to flash floods on lands vulnerable to rising tides. The inevitable scenarios portrayed by computer models predicting human adaptation patterns required to mitigate deleterious consequences of rising tides will necessitate nothing less than innovative harmonious ecological stewardship, a more equitable sharing of natural resources, the cessation of ostentatious dwellings and other egalitarian approaches to natural preservation reducing erosion and enhancing biodiversity among human and other species in urban areas. Guallart states that the occupier, and his or her inhabitation, develop as a member of a group. In this way, social commitment, seen as a free form of elective relationship, is based on shared systems of tapping resources, general programs of sustainability and integrated management networks by means of non-aggressive positioning and installation in the territory. It is then, a sustainable system of revitalization, [...] which turns the dwelling and its inhabitants into a mechanism of support. ${ }^{22}$

Might the Wagonburg utopian caravan collective network in and beyond Wroclaw Poland eventually represent a revolutionary housing movement that not only refrains from colonizing city territories but also heals and revitalizes the city after experiencing devastation brought on by uneven development and ecological disasters? Only time will tell if urban officials will continue to outlaw, criminalize and harass these unique inhabitants, or, if European public policies will finally foster and strengthen the revitalization efforts of these experimental sustainable squatting communities for the benefit of the people and the planet in the future.

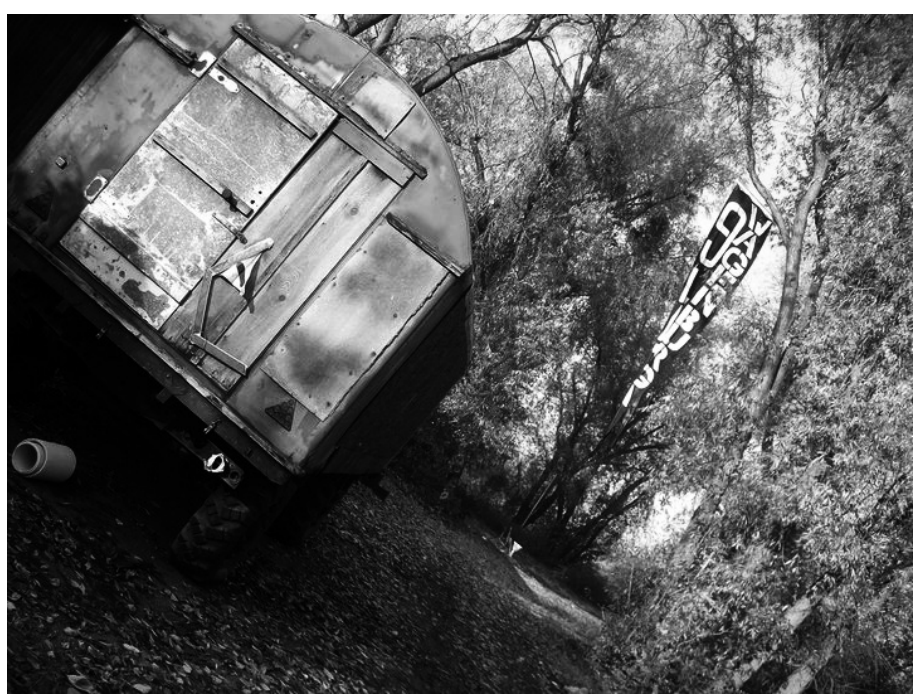


Jennifer Siegel, ed., Mobile: The Art of Portable Architecture (Princeton: Princeton Architectural Press, 2002), and Lebbeus Woods, The New City (New York: Touchstone, 1992).

For more informarion see: Nancy B. Solomon, ed., Architecture: celebrating the past, designing the future? (Visual Reference Publications, 2008), Rebecca Kneale Gould, At home in nature: modern homesteading and spiritual practice in America (Davis, CA: University of California, 2005) and Maida Samuel et al., The European Caravan: An Anthology of the New Spirit in European Literature (New York: Brewer, Warren, \& Putnam, 1931). Chicago, 1923) and Todd DePastino, Citizen Hobo: how a century of homelessness shaped America (Chicago, IL: University of Chicago, 2003). Sequence (Cambridge: Cambridge University,2005). Christopher Kennedy, The Evolution of Great World Cities: Urban Wealth and Economic Growth (Toronto, CA: University of Toronto,2011), 40-43. 
Immanuel Wallerstein, The Essential Wallerstein (New York: New Press, 2000).

Catherine Slessor, Eco-Tech: Sustainable Architecture and High Technology (New York: Thames and Hudson, 1997), 15-16.

Attila Kotanyi and Vaneigem, Raoul. ' Elementary Program of the Bureau of Unitary Urbanism Manifesto," Internationale Situationniste 6 (1961).

Woods, The New City, x.

Vera Lemecha, "Introduction" in The Feminist Reconstruction of Space, ed.Vera Lemecha et al. (Manitoba: St. Norberts Arts, 1996), 7.

Ibid.

Jane Rendell, "doing it, (un)doing it, (over)doing it yourself Rhetorics of Architectural Abuse in Occupying Architecture Between the Architect and the User, ed. Jonathan Hill (London: Routledge, 1998), $235-242$.

Jeffrey Craig Sander, 'Building an "Urban Homestead" in Greening the City: Urban Landscapes in the Twentieth Century, ed. Dorothee Brantz and Sonja Dumpelmann (Charlotesville: University of Virginia, 2011), $182-198$.

Rendall, "doing it, (un)doing it, (over)doing it yourself Rhetorics of Architectural Abuse in Occupying Architecture Between the Architect and the User", 235-242.

Slessor, Eco- tech, 7.

Allan Cochrane, Foreword to Mobile Urbanism Cities and Policymaking in the Global Age, ed., Eugene McCann and Kevin Ward (Minneapolis, Minnesota: University of Minnesota, 2011), xv. Lisiunia Romanienko, Body Piercing and Identity Comparative Perspectives (New York, New Orleans, and Wroclaw: Palgrave Macmillan, 2011), 206.

Karsten Harries, The Ethical Functions of Architecture (London, UK: MIT, 1997), 144-172.

Vincente Guallart, "Self sufficient habitat," in Self-Sufficient Housing, ed. Vincente Guallart, Willy Muller and Lucas Cappelli (Barcelona, Spain: Actar Pr., 2006), 6-11.

Michael Vargas Moya, "Nomad Refuge," in Self-Sufficient Housing, ed. Vincente Guallart, Willy Muller and Lucas Cappelli (Barcelona, SP: Actar Pr., 2006), 111.

Ibid., 287-289.

Anderson, Nels. The Hobo: The Sociology of the Homeless Man. Chicago, IL: University of Chicago, 1923.

Body-Gendrot, Sophie. Social Control of Cities? A Comparative Perspective. Oxford, UK: Blackwell, 2000.

Cochrane, Allan. Foreword to Mobile Urbanism Cities and Policymaking in the Global Age, ed. Eugene McCann and Kevin Ward, Minneapolis, Minnesota: University of Minnesota, 2011.

DePastino, Todd. Citizen Hobo: how a century of homelessness shaped America. Chicago, IL: University of Chicago, 2003.

Friedmann, John. Planning in the Public Domain: From Knowledge to Action. Princeton, NJ: Princeton University, 1987.

Guallart, Vincente. "Self sufficient habitat." In Self-Sufficient Housing, ed. Vincente Guallart, Willy Muller and Lucas Cappelli, Barcelona, Spain: Actar Pr., 2006.

Harries, Karsten. The Ethical Functions of Architecture. London, UK: MIT, 1997.

Inglehart, Ronald. Modernization, Cultural Change, and Democracy The Human Development Sequence. Cambridge, UK: Cambridge University, 2005.

Kennedy, Christopher. The Evolution of Great World Cities: Urban Wealth and Economic Growth. Toronto, CA: University of Toronto, 2011. 
Kneale Gould, Rebecca. At home in nature: modern homesteading and spiritual practice in America. Davis, CA: University of California, 2005.

Kotanyi, Attila and Raoul Vaneigem. ' 'Elementary Program of the Bureau of Unitary Urbanism Manifesto.” Internationale Situationniste 6 (1961).

Lemecha, Vera. "Introduction" in The Feminist Reconstruction of Space, ed. Lemecha, Vera, Eleanor Bond, Louise W. May, Rita McKeough, Shawna Dempsey, Lorri Millan, Bev Pike and Nancy McKinnon. Manitoba, CA: St. Norberts Arts, 1996.

Moya, Michael Vargas. "Nomad Refuge" in Self-Sufficient Housing. ed. Guallart, Vincente, Willy Muller and Lucas Cappelli, Barcelona, SP: Actar Pr., 2006.

Pateman, Carole. Participation and Democratic Theory. Cambridge, UK: Cambridge University, 1970.

Rendell, Jane. "doing it, (un)doing it, (over)doing it yourself Rhetorics of Architectural Abuse in Occupying Architecture Between the Architect and the User. ed. Hill, Jonathan. London, UK: Routledge, 1998.

Romanienko, Lisiunia. Body Piercing and Identity Comparative Perspectives. New York, New Orleans, and Wroclaw: Palgrave Macmillan, 2011.

Sadler, Simon. The Situationist City. London, UK: MIT, 1998.

Sander, Jeffrey Craig. "Building an "Urban Homestead"”, in Greening the City: Urban Landscapes in the Twentieth Century. ed. Brantz, Dorothee and Sonja Dumpelmann. Charlotesville, VA: University of Virgini, 2011.

Siegel, Jennifer. ed. Mobile: The Art of Portable Architecture. Princeton, NJ: Princeton Architectural Press, 2002.

Slessor, Catherine. Eco-Tech: Sustainable Architecture and High Technology. NY, NY: Thames and Hudson, 1997.

Solomon, Nancy B. ed. Architecture: celebrating the past, designing the future?. Visual Reference Publications, 2008.

Samuel, Maida, Darnton Castelhun, George Reavey and J. Bronowski. ed. The European Caravan: An Anthology of the New Spirit in European Literature. NY, NY: Brewer, Warren, \& Putnam, 1931.

Wallerstein, Immanuel. The Essential Wallerstein. New York: New Press, 2000.

Woods Lebbeus. Anarchitecture Architecture Is a Political Act. St Martins Press, 2002.

Woods, Lebbeus. The New City. NY, NY: Touchstone, 1992. 
KARAVAN KOLEKTIVI:

URBANO EKOLOŠKO IZGNANSTVO U MILITANTNE MARGINALNE PROSTORE

\section{Lisiunia A. Romanienko}

Žestina kojom siromaštvo istrajava u novim državama članicama EU predstavlja značajan izazov za one koji su zainteresovani za zalaganje za stambene probleme onih u urbano nepovoljnom položaju. Postkomunističke zemlje poput Poljske su stekle nezavidno nasleđe ruševnog komunističkog stanovanja u blokovima koje predstavlja svaremene uslove koji obuhvataju koncentraciju nasilnog kriminala, napada na estetske senzibilitete i ozbiljne smetnje za održivi život. Druge stambene alternative su projekti masivne izgradnje stambenih objekata koje sprovode strani graditelji velikih novogradnji, što dovodi do lažne oskudice i spiralnih troškova. U odgovoru na ove štetne uslove, anarhistički aktivisti ljubitelji ekološkog života su izašli sa naprednim predlogom još jedne alternative za stambenu krizu putem mobilne arhitektonske anarhije. Recikliranjem mobilne arhitekture u obliku modifikacije napuštenih železničkih vagona i putovanja u malim materijalnoneopterećenim zajednicama, ove grupe ili karavani često naginju neformalnom naseljavanju ili skvotiranju u perifernim, odbačenim ekološkim oblastima u gradovima da bi unapredili nezavisni održivi način života poznat kao stvaranje urbanog doma porodice. Ovi pioniri migrirajućeg stanovanja, poznati i kao novi hobosi, su prigrlili svoj potčinjeni status, prihvatili svoj identitet građana bez državljanstva u stalnom izgnanstvu, i unapredili nehijerarhijski održivi način života. Analiza će dati studiju slučaja posmatranjem uz participaciju u poljskoj eko anarhističkoj karavan zajednici, opisaće prepreke za kolektivni postupak, i daće okvir za ovaj fenomen u svetlu korišćenja marginalnih territorijalnih skvotiranja da bi inspirisao evropsku stambenu politiku da proširi ovo egalitarno stambeno rešenje za gradove u budućnosti.

KLJUČNE REČI: ODRŽIVI ŽIVOT, URBANO SKVOTIRANJE, EVROSPKA STAMBENA POLITIKA, PROTIV

VELIKE STAMBENE NOVOGRADNJE

URBANE TRANZICIJE U PRAVCU ODRŽIVOSTI -

UČITI IZ GRACA I FRAJBURGA?

Harald Rohrachera, Philipp Späthb

Inovacione politike u Evropskoj Uniji se sve više bave tzv „,velikim izazovima“ kao što su klimatske promene, iscrpljivanje izvrora ili starenje društava. Takve transformacije daleko prevazilaze inovacije konvencionalnih proizvoda ili procesa i zahtevaju restruktuiranje širokih drušveno-tehnoloških režima, na 